\title{
Ordovician arc ophiolite, the Hayachine and Miyamori complexes, Kitakami Mountains, Northeast Japan: isotopic ages and geochemistry
}

\author{
Ken Shibata $^{1}$ and Kazuhito Ozawa ${ }^{2}$ \\ Geological Survey of Japan, Tsukuba $305^{1}$, \\ and Geological Institute, University of Tokyo, Tokyo $113^{2}$, Japan
}

(Received January 8, 1992; Accepted March 26, 1992)

\begin{abstract}
$\mathrm{Sm}-\mathrm{Nd}, \mathrm{Rb}-\mathrm{Sr}$ and $\mathrm{K}-\mathrm{Ar}$ geochronological and isotopic analyses were made on the HayachineMiyamori arc ophiolite in the Kitakami Mountains, Northeast Japan. The Sm-Nd isochron for four whole-rock samples gives an age of $510 \pm 70 \mathrm{Ma}$ and an initial ${ }^{143} \mathrm{Nd} /{ }^{144} \mathrm{Nd}$ ratio of $0.51229 \pm 0.00010$ $\left(\varepsilon_{\mathrm{Nd}}=+6.4 \pm 2.0\right)$. The initial $\varepsilon_{\mathrm{Nd}}$ for individual rocks ranges from +6.3 to +7.0 , and is lower than that of the MORB. The age of $510 \mathrm{Ma}$ is interpreted to represent the crystallization age of the HayachineMiyamori ophiolite. K-Ar ages of eight hornblendes range from 244 to $473 \mathrm{Ma}$, within which ages younger than about $400 \mathrm{Ma}$ are thought to be affected by Cretaceous granitic intrusions. The $\mathrm{K}-\mathrm{Ar}$ hornblende ages may indicate the times of tectonic emplacement to shallower levels.

The initial ${ }^{87} \mathrm{Sr} /{ }^{86} \mathrm{Sr}$ ratios of eight whole rock samples from the Hayachine-Miyamori complexes show a wide variation: ranging from -4.0 to +31.9 as $\varepsilon_{\mathrm{Sr}}$. The nearly constant $\varepsilon_{\mathrm{Nd}}$ and variable $\varepsilon_{\mathrm{Sr}}$ suggest various extent of seawater alteration for these samples. Amphibolites whose protolith may be extrusive or shallow intrusive rocks give higher $\varepsilon_{\mathrm{Sr}}$ than plutonic rocks, which is consistent with circulation of sea water during the metamorphism. However, coarse-grained gabbro intruded into host peridotites still have higher $\varepsilon_{\mathrm{Sr}}$ than the MORB. The lower $\varepsilon_{\mathrm{Nd}}$ and higher $\varepsilon_{\mathrm{Sr}}$ for these gabbroic rocks, which occur in the host peridotites with arc-related geochemical characteristics, suggest that these isotopic signatures were recorded within an arc upper mantle. This mantle signature may be explained by an involvement of radiogenic fluid or melt derived from subducting slab, which had been altered by sea water at a midocean ridge.
\end{abstract}

\section{INTRODUCTION}

Many ophiolites show unequivocal differences from major oceanic crust and upper mantle in many aspects (Dick and Bullen, 1984; Dick and Fisher, 1984; Pearce et al., 1984), and they are considered to be mostly formed in arcrelated environment, such as back arc basin, fore arc, or embryonic arc. One of the most remarkable differences between ophiolites and major oceanic crust-upper mantle is geochemical characteristics of many ophiolites indicating the similar signature of the present-day arc magmatisms (Pearce et al., 1984). In spite of the abundant geochemical data indicating arc signature on extrusive or shallow intrusive rocks, ultramafic rocks commonly do not show clear geochemical characteristics of arc magmas. The Miyamori ophiolitic complex is exceptional in this sense, because its ultramafic rocks contain abundant hydrous phases exhibiting evident arcrelated geochemical characteristics (Ozawa, 1988; Ozawa and Shimizu, 1991). This indicates that in the Miyamori complex generation mechanism of geochemical signature for arc magmatism can be traced back to the upper mantle, where melting and melt segregation of primitive magmas took place.

The Miyamori complex was transported to the present position from the Hayachine Tec- 
tonic Belt, where the Hayachine ophiolitic complex occurs. These two complexes were emplaced in the Ordovician time along the Hayachine Tectonic Belt (Ozawa et al., 1988) and share the common petrologic and geologic characteristics. They can be grouped as one complex and can be called Hayachine-Miyamori ophiolite.

In order to understand processes involved in arc magmatisms from partial melting to volcanic activities in the Hayachine-Miyamori ophiolite, complete data set for trace elements and isotope geochemistry are absolutely necessary. Ozawa (1988) presented mineralogical data with which qualitative characterizations of the mantle processes are possible. However, those geochemical data have not yet been obtained, because of difficulties arising from strong alteration and late-stage metamorphism by Cretaceous granitic intrusions.

This paper presents $\mathrm{Nd}$ and $\mathrm{Sr}$ isotope data of the Hayachine-Miyamori ophiolitic complexes along with dating by $\mathrm{K}-\mathrm{Ar}$ method on hornblende separates and Sm-Nd method on whole rocks. Analyses were made on gabbroic rocks because their mafic phase tends to preserve more primary mineralogy than ultramafic rocks. These data confirmed that the HayachineMiyamori ophiolite was formed in an arc environment in the Ordovician time. Origin of geochemical features characterizing arc volcanisms are discussed on the basis of the geochemical and mineralogical data obtained so far.

\section{Geologic Setting}

The Hayachine and Miyamori ophiolitic complexes are located in the Kitakami Mountains in Northeast Japan (Fig. 1). The Hayachine complex and petrologically similar but smaller maficultramafic complexes and extrusive members probably related to the complexes define "Hayachine Tectonic Belt", which divides the Kitakami Mountains into two geologically distinguishable domains formed in contrasting sedimentary environments (Onuki, 1969). The South Kitakami is characterized by dominance

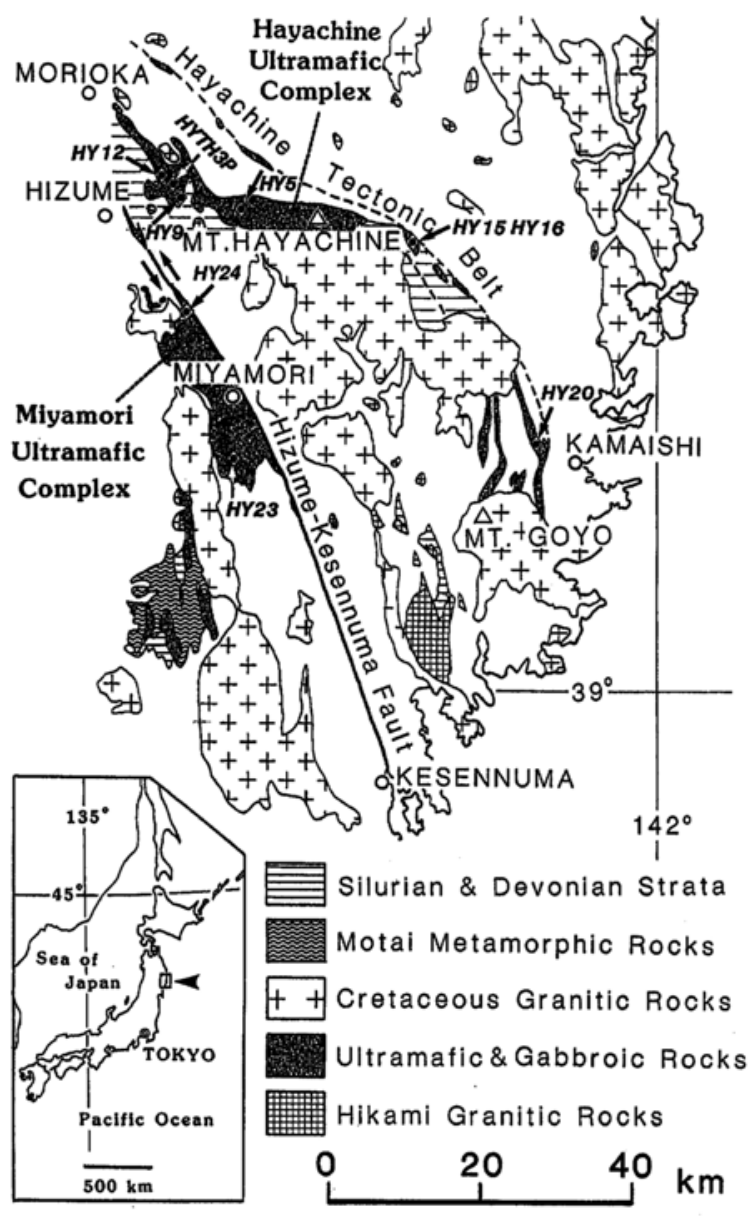

Fig. 1. Geologic outline of the Hayachine-Miyamori ophiolitic complexes. Sample localities are also shown.

of sandstone, mudstone, and limestone and has considerable distribution of Silurian, Devonian and possibly Ordovician sedimentary rocks (Ehiro et al., 1988). On the contrary, the North Kitakami is composed mainly of chert and basic extrusive rocks of Triassic to Jurassic ages. On the basis of this contrast and geological transition from the North to South Kitakami, various tectonic histories of the Kitakami Mountains are proposed (Saito and Hashimoto, 1982; Osawa, 1983; Kato, 1985; Ehiro et al., 1988; Ozawa et al., 1988).

The Hayachine and Miyamori complexes are now separated by the Hizume-Kesennuma fault, but they were forming one large arc ophiolitic complex when they emplaced in the Ordovician 
time along the Hayachine Tectonic Belt (Ozawa et al., 1988). The part of the large complex (Miyamori complex) was displaced to the south in the early Cretaceous by the left lateral strike slip movement of the Hizume-Kesennuma fault (Ehiro, 1977; Ozawa, 1984; Ozawa et al., 1988). According to these tectonic reconstructions and the common petrologic and geologic features, the Miyamori and Hayachine complexes are referred together as the Hayachine-Miyamori ophiolite in this paper.

The detailed geologic and petrologic studies of the Miyamori complex were made by Ozawa $(1983,1988)$. The complex consists of ultramafic tectonite and cumulate members that are intruded by clinopyroxene hornblende gabbro, clinopyroxene hornblendite, dolerite, and felsic porphyritic intrusive rocks (Seki, 1952; Ozawa, 1984). The tectonite member is composed mostly of hornblende-bearing harzburgite and dunite, the cumulate member, mainly of hornblendebearing dunite, plagioclase-free or -bearing wehrlite, and olivine clinopyroxenite. They have the typical structural and chemical characteristics of the basal, ultramafic portion of an ophiolite (Ozawa, 1983).

The geology of the Hayachine complex has not yet been well understood. There are papers on geology of the surrounding area (Osawa, 1983; Ehiro et al., 1988), but no detailed study on the complex itself has yet been done. A reconnaissance in the western part of the Hayachine Tectonic Belt shows that there is rough ophiolitic stratigraphy with substantial tectonic complications. The residual peridotites occur in the central zone of the Hayachine Tectonic Belt, whose southern margin is fringed by gabbro-diabase intrusive complexes. To the south of this intrusive complexes, abundant basic extrusive rocks occur, which are most widely distributed to the east of Hizume. These basic extrusive rocks are covered by probably Silurian-Ordovician sedimentary rocks in the Ohasama area (Ehiro et al., 1988). Amphibolite and clinopyroxene hornblende gabbros of the Hayachine complex occur as tectonic blocks with several meter to several tens of meter size and are in fault contact with surrounding serpentinite or pelitic schist (Okami and Oishi, 1983). In the Miyamori complex, hornblende gabbro and hornblendite occur as elongate bodies in the host peridotites. They are interpreted to be late-intrusives (Ozawa, 1984).

\section{Petrography and Geologic Background OF THE STUdied SAMPLES}

Sampling locality: west of Nagano Path, Morioka City, Iwate Prefecture $\left(39^{\circ} 34.0^{\prime} \mathrm{N}\right.$, $\left.141^{\circ} 21.0^{\prime} \mathrm{E}\right)$

Sample no.: HY-5

Rock type: hornblende gabbro

The exposure of this gabbro is very poor, but lineated gabbro (or amphibolite?) with similar lithology is in fault contact with serpentinite 100 $\mathrm{m}$ to the NE of this locality. The gabbro shows marked lineation and consists mainly of brownish green to pale green hornblende $(2 \sim 0.1 \mathrm{~mm})$ and saussuritized plagioclase (2 $0.1 \mathrm{~mm})$. Rounded grains of clinopyroxene are present as inclusions in or along grain boundaries of hornblende grains. Hornblende contains rounded plagioclase inclusions. Apatite, $0.07 \sim 0.02 \mathrm{~mm}$ long, is present as an aggregate. Hornblende is very fresh with limited replacement by colorless amphibole along its margin. Saussurite is composed of prehnite, albite, grossular. Veins of prehnite, albite, and epidote are present. Its thickness ranges from 0.5 to 0.01 $\mathrm{mm}$.

Sampling locality: west of Itsutsuha, Shiwa Town, Shiwa-gun, Iwate Prefecture $\left(39^{\circ} 35.1^{\prime} \mathrm{N}\right.$, $\left.141^{\circ} 17.3^{\prime} \mathrm{E}\right)$

Sample no.: HY-9

Rock type: amphibolite

This amphibolite is in fault contact with serpentinite on the east and is probably tectonic block at least $5 \mathrm{~m}$ across. This rock consists mainly of hornblende $(1.5 \sim 0.1 \mathrm{~mm}$ in size) with greenish brown to pale brown pleochroism and saussuritized plagioclase $(0.4 \sim 0.2 \mathrm{~mm})$. It exhibits remarkable lineation, defined by linear preferred shape orientation of hornblende, plagioclase, and sphene. The hornblende and 
plagioclase show typical tabular equigranular texture, and the texture is different from that of epidote amphibolite occurring in a fenster of the Miyamori complex, which is characterized by serrated grain boundaries of hornblende. Euhedral sphene, $0.2 \sim 0.1 \mathrm{~mm}$ long, commonly occurs as inclusions in hornblende as in the case of the epidote amphibolite from the Miyamori complex. It also occurs along grain boundaries of main constituent minerals and enclosed in plagioclase. In any case, sphene exhibits marked preferred shape orientation that is parallel to the lineation. The occurrence of euhedral sphene enclosed in hornblende is a characteristics of amphibolite or epidote amphibolite in the Hayachine-Miyamori ophiolite. Sphene also occurs in hornblendite or hornblende gabbro, but it is always secondary, replacing ilmenite or hornblende. Hornblende is fairly fresh but tends to become colorless or pale green along its margin or cleavage. This alteration is generally observed along prehnite vein $(0.1 \sim 0.2 \mathrm{~mm}$ in thickness). Saussurite is composed of grossular, albite, sericite, and prehnite.

Sampling locality: southwest of Itayama, Tonan Village, Shiwa-gun, Iwate Prefecture $\left(39^{\circ} 35.7^{\prime} \mathrm{N}, 141^{\circ} 15.6^{\prime} \mathrm{E}\right)$

Sample no.: HY-12

Rock type: metagabbro

The locality is within the gabbro-basic intrusive complexes. The contact relationships with surrounding rocks are not clear in this locality. The main constituent minerals are anhedral pale green to colorless amphibole and dusty euhedral to subhedral plagioclase. Plagioclase is 4 0.5 mm long and has fine-grained inclusions of epidote, chlorite, amphibole, grossular, and sericite. Pale green amphibole has brown patches, suggesting that the amphibole is formed by the replacement of brown primary hornblende. Brown hornblende very rarely occurs as an isolated crystal with $0.5 \mathrm{~mm}$ size. Plagioclase has patches or veins of glossular or epidote. Clear veins of albite are also observed. The minor constituent minerals are euhedral to subhedral apatite $(0.4 \sim 0.2 \mathrm{~mm})$ and pseudomorph of magnetite and ilmenite aggregate $(1 \sim 0.1 \mathrm{~mm})$. They are completely replaced by chlorite and sphene. Albite veins ( $1 \sim 0.1 \mathrm{~mm}$ wide) and veins (2 $\sim 0.5 \mathrm{~mm}$ wide) consisting of epidote and chlorite are present. This metagabbro is interpreted to be a gabbro containing plagioclase, brown hornblende, magnetite, ilmenite, and probably substantial amounts of clinopyroxene, which was metamorphosed at relatively low temperature conditions. The texture characterized by euhedral plagioclase and anhedral mafic minerals is different from hornblende gabbros commonly observed in the Hayachine-Miyamori complexes, suggesting that it is a shallow intrusive. This is consistent with the association of fine grained basic rocks, which are extrusive rocks and shallow intrusives in this area.

Sampling locality: east of Kagura, Kawai Village, Shimohei-gun, Iwate Prefecture $\left(39^{\circ} 30.9^{\prime} \mathrm{N}, 141^{\circ} 38.3^{\prime} \mathrm{E}\right)$

Sample no.: HY-15

Rock type: clinopyroxene hornblende gabbro

The sample is from gabbroic zone of the Kagura mass (Onuki, 1962). The gabbroic zone is probably in fault contact with serpentinite on the east and is gradational contact with basic intrusive complexes on the west. This gabbro exhibits marked foliation and consists mainly of brown to pale brown hornblende $(5 \sim 0.2 \mathrm{~mm}$ long), clinopyroxene (1.5 0.2 $\mathrm{mm}$ long), and saussuritized plagioclase ( $<5 \mathrm{~mm}$ long). It also contains magnetite and ilmenite $(0.5 \sim 0.05 \mathrm{~mm})$, which are replaced by chlorite, sphene, and green amphibole. Saussurite is composed mostly of zoisite and contains chlorite and calcite. Brown hornblende is replaced by green amphibole associated with tiny sphene along its margin and cleavage. Clinopyroxene is replaced by pale green amphibole and chlorite along its margin and cleavage. Veins, $0.5 \sim 0.05 \mathrm{~mm}$ wide, composed of pale green hornblende, chlorite, and calcite are present.

Sampling locality: east of Kagura, Kawai Village, Shimohei-gun, Iwate Prefecture $\left(39^{\circ} 30.9^{\prime} \mathrm{N}, 141^{\circ} 38.3^{\prime} \mathrm{E}\right)$ 
Sample no.: HY-16

Rock type: clinopyroxene hornblende gabbro

The geology is the same as that of HY-15 described above. It consists mainly of brown to pale brown hornblende $(1 \sim 0.1 \mathrm{~mm})$, clinopyroxene $(1 \sim 0.1 \mathrm{~mm})$, and completely saussuritized plagioclase. They exhibits preferred shape orientation, which brings about the marked foliation. Euhedral to subhedral apatite, $0.2 \sim 0.05 \mathrm{~mm}$ long, is present. Hornblende is replaced by pale green to colorless amphibole associated with tiny sphene along its margin and cleavage. Clinopyroxene is replaced by chlorite, pale brown to colorless amphibole along its margin and cleavage. Some clinopyroxene grains are replaced by patches of brown hornblende. As a whole clinopyroxene is well preserved. Saussurite is composed of zoisite, grossular, and chlorite. Albite veins with $0.4 \sim 0.02 \mathrm{~mm}$ thickness are present.

Sampling locality: northwest of Osano, Kamaishi City, Iwate Prefecture $\left(39^{\circ} 16.9^{\prime} \mathrm{N}\right.$, $\left.141^{\circ} 49.3^{\prime} \mathrm{E}\right)$

Sample no.: HY-20

Rock type: hornblende gabbro

This rock consists mainly of greenish brown to pale brown hornblende $(1 \sim 0.1 \mathrm{~mm})$ and saussuritized anhedral plagioclase $(2 \sim 0.05 \mathrm{~mm})$, and exhibits weak foliation. Hornblende contains euhedral apatite $(0.4 \sim 0.05 \mathrm{~mm})$ and magnetite and ilmenite $(0.2 \sim 0.05 \mathrm{~mm})$, which are altered into haematite. Greenish brown hornblende rarely contains rounded clinopyroxene inclusions $0.05 \mathrm{~mm}$ in diameter. Hornblende is replaced by colorless amphibole along its margin and cleavage and each grain has several domains showing different extinction angle, which suggests plastic deformation. Crystal aggregates composed of fine-grained colorless to pale green acicular amphibole, chlorite, and sphene are present. They are in sharp contact with greenish brown hornblende, suggesting that they are pseudomorphs of clinopyroxene. Therefore, the most of secondary amphibole listed in Table 1 is considered to have been clinopyroxene before the alteration. Saussurite is composed of grossular, albite, and chlorite, and locally cut by albite veins. Euhedral apatite with $0.2 \sim 0.05 \mathrm{~mm}$ size is present in hornblende or along grain boundaries of the main constituent minerals.

Sampling locality: south of Kuromori, Tonan Village, Shiwa-gun, Iwate Prefecture $\left(39^{\circ} 35.6^{\prime} \mathrm{N}, 141^{\circ} 16.6^{\prime} \mathrm{E}\right)$

Sample no.: HYTH3P

Rock type: amphibolite

This amphibolite occurs in the gabbrodiabase intrusive complexes. It has well developed lineation and saussuritized plagioclase. It is surrounded by much more felsic intrusive rocks but the contact is not exposed. Hornblende is greenish brown or brownish green to pale brown with 1 to $0.1 \mathrm{~mm}$ length. Rarely large grains of plagioclase or hornblende up to $2 \mathrm{~mm}$ in size are present. They are elongate parallel to the lineation. Euhedral sphene with $0.05 \mathrm{~mm}$ size is abundant as observed in HY-9. Euhedral apatite with $0.03 \sim 0.01 \mathrm{~mm}$ size is also present. Sphene and apatite are commonly enclosed in hornblende or plagioclase. Hornblende is very fresh and there is no secondary amphibole except for the margin of grains in contact with chlorite veins. Prehnite veins $(0.1 \sim 0.05 \mathrm{~mm}$ in thickness) and veins composed of chlorite and albite $(0.3 \sim 0.05 \mathrm{~mm}$ in thickness) are present. Saussurite is composed of albite, prehnite, zoisite, grossular, and sericite.

Sampling locality: northwest of Gorin Path, Towa Town, Waga-gun, Iwate Prefecture $\left(39^{\circ} 16.1^{\prime} \mathrm{N}, 141^{\circ} 20.9^{\prime} \mathrm{E}\right)$

Sample no.: HY-23

Rock type: plagioclase-bearing hornblende clinopyroxenite

This sample is from an ultramafic-mafic complex in the cumulate member of the Miyamori complex. This complex might be an intrusive into the cumulate member or melt rich pocket surrounded by ultramafic cumulates. The complex consists of cortlandite, olivine hornblende clinopyroxenite, plagioclase-bearing or -free hornblende clinopyroxenite, clinopyroxene hornblendite, and clinopyroxene hornblende gabbro. They are systematically distributed from the east 
Table 1. Modal composition of the Hayachine-Miyamori ophiolitic complexes dated by $K$-Ar method

\begin{tabular}{|c|c|c|c|c|c|c|c|c|c|c|}
\hline Sample no. & Rock type & $\mathrm{cpx}$ & rcp & phb & rhb & $\mathrm{pl}$ & ilm & apt & $\mathrm{sph}^{* *}$ & ven \\
\hline \multicolumn{11}{|c|}{ Hayachine complex } \\
\hline HY-5 & Hb gabbro & tr. & - & 54.0 & 1.0 & 43.6 & - & tr. & - & 1.4 \\
\hline HY-9 & Amphibolite & - & - & 54.5 & 2.3 & 38.6 & - & 0.1 & 1.2 & 3.3 \\
\hline HY-12 & Doleritic metagabbro & - & - & 2.4 & 36.7 & 53.3 & 1.2 & 0.1 & - & 6.3 \\
\hline HY-15 & Cpx-hb gabbro & 6.9 & 8.2 & 46.2 & 13.7 & 20.4 & 1.3 & - & - & 3.3 \\
\hline HY-16 & Cpx-hb gabbro & 13.7 & 5.0 & 20.5 & 11.4 & 45.7 & - & tr. & - & 3.7 \\
\hline HY-20 & Hb gabbro & tr. & $-{ }^{*}$ & 45.9 & 31.5 & 20.1 & tr. & 0.4 & - & 2.1 \\
\hline НYTH3P & Amphibolite & - & - & 50.3 & 1.8 & 41.4 & - & tr. & 2.8 & 3.7 \\
\hline \multicolumn{11}{|c|}{ Miyamori complex } \\
\hline HY-23 & Hb clinopyroxenite & 47.8 & - & 39.5 & 3.8 & 8.6 & 0.2 & 0.1 & - & - \\
\hline
\end{tabular}

-: not present, tr.: trace amount present (less than $0.1 \%$ ).

Abbreviations of mineral names are as follows; cpx: clinopyroxene, rcp: chlorite and amphibole replacing clinopyroxene, phb: primary hornblende, rhb: secondary amphibole and chlorite replacing hornblende, pl: plagioclase (altered into saussurite), ilm: ilmenite and magnetite (including sphene replacing ilmenite), apt: apatite, sph: sphene, ven: vein minerals (albite, chlorite, prehnite, epidote, and calcite).

*Amphibole and chlorite after clinopyroxene are included in those after primary amphibole, because of difficulty in identification of primary minerals.

**Primary sphene. All rocks contain trace amounts of secondary sphene.

to the west in the order listed above. This rock has porphyritic appearance, exhibited by large euhedral green hornblende "phenocryst", 3 $\mathrm{cm} \sim 5 \mathrm{~mm}$ long, set in a medium-grained matrix consisting mainly of euhedral to subhedral clinopyroxene $(2 \sim 0.2 \mathrm{~mm})$ and interstitial saussuritized plagioclase. Clinopyroxene is generally replaced by patches of hornblende. Hornblende shows pale greenish brown to pale green pleochroism. It becomes almost colorless with slight greenish tint where it is recrystallized into finer grains by deformation or replaced by chlorite. Large euhedral hornblende encloses abundant euhedral clinopyroxene grains with the same size as in matrix. Subhedral apatite $(0.5 \sim 0.3 \mathrm{~mm})$ is present as an inclusion in large hornblende and in matrix. Saussurite is composed of zoisite, grossular, albite. Haematite, chlorite, epidote, and sphene are present as secondary phases.

Modal composition of dated samples from the Hayachine-Miyamori complexes is given in Table 1. Description and modal composition of sample HY-24(AG4-2) are given in Ozawa et al. (1988).

\section{Analytical Procedures}

$\mathrm{K}-\mathrm{Ar}$ ages were determined on hornblendes separated from rocks of the HayachineMiyamori ophiolite. The analytical method was the same as described in Ozawa et al. (1988).

$\mathrm{Sm}-\mathrm{Nd}$ and $\mathrm{Rb}-\mathrm{Sr}$ analyses were made on whole-rock samples of the Hayachine-Miyamori ophiolite. Sm and Nd concentrations were determined by isotope dilution method, whereas $\mathrm{Rb}$ and $\mathrm{Sr}$ concentrations were determined by either $\mathrm{X}$-ray fluorescence or isotope dilution method. The ${ }^{143} \mathrm{Nd} /{ }^{144} \mathrm{Nd}$ and ${ }^{87} \mathrm{Sr} /{ }^{86} \mathrm{Sr}$ ratios were determined for unspiked solutions, and normalized to ${ }^{146} \mathrm{Nd} /{ }^{144} \mathrm{Nd}=0.7219$ and ${ }^{86} \mathrm{Sr} /{ }^{88} \mathrm{Sr}=0.1194$. Replicate analyses of LaJolla and E \& A standards gave ${ }^{143} \mathrm{Nd} /{ }^{144} \mathrm{Nd}$ and ${ }^{87} \mathrm{Sr} /{ }^{86} \mathrm{Sr}$ ratios of $0.51184 \pm 0.00002(2 \sigma)$ and $0.70809 \pm 0.00004$ $(2 \sigma)$, respectively. Sm-Nd age was calculated by the least-square method of York (1966), using error of $0.5 \%(1 \sigma)$ for ${ }^{147} \mathrm{Sm} /{ }^{144} \mathrm{Nd}$ ratio and errors given in Table 3 for ${ }^{143} \mathrm{Nd} /{ }^{144} \mathrm{Nd}$ ratio. Errors in Sm-Nd age and initial ratio are given on $2 \sigma$ level. As the ${ }^{143} \mathrm{Nd} /{ }^{144} \mathrm{Nd}$ ratio of the LaJolla standard in this study was lower by 0.00002 than that of Lugmair and Carlson (1978), 0.00002 is added for the calculation of $\varepsilon_{\mathrm{Nd}}$. Errors in ${ }^{87} \mathrm{Sr} /{ }^{86} \mathrm{Sr}$ measurements were less than $0.01 \%$ at 
$2 \sigma$ mean level.

Decay constants used in age calculation are: ${ }^{40} \mathrm{~K} \quad \lambda_{\beta}=4.962 \times 10^{-10} / \mathrm{y},{ }^{40} \mathrm{~K} \quad \lambda_{\mathrm{e}}=0.581 \times$ $10^{-10} / \mathrm{y},{ }^{40} \mathrm{~K} / \mathrm{K}=0.01167$ atom $\%,{ }^{87} \mathrm{Rb} \lambda=1.42$ $\times 10^{-11} / \mathrm{y},{ }^{147} \mathrm{Sm} \lambda=6.54 \times 10^{-12} / \mathrm{y}$.

\section{Results}

$\mathrm{K}-\mathrm{Ar}$ ages of hornblendes from five gabbroic rocks, two amphibolites and one hornblende clinopyroxenite are given in Table 2. Ages range from 244 to $473 \mathrm{Ma}$, but those younger than about $400 \mathrm{Ma}$ are thought to be affected by the Cretaceous granitic intrusions as discussed later. Excluding them, the $\mathrm{K}-\mathrm{Ar}$ ages of hornblendes from the Hayachine complex are similar to ages of $421-484 \mathrm{Ma}$ for the Miyamori complex (Ozawa et al., 1988), confirming that the Miyamori complex was originally emplaced along the "Hayachine Tectonic Belt" as a part of the Hayachine-Miyamori ophiolite (Ozawa, 1984).

Sm-Nd isotopic data for four whole-rock samples are given in Table 3, and are also plotted on an isochron diagram (Fig. 2). Although four samples are collected from a wide area in the Hayachine and Miyamori complexes, they are believed to be derived from a common source material, because the terrane shares the common characteristics in geology, petrology, and $\mathrm{K}-\mathrm{Ar}$ hornblende age (Onuki, 1962; Osawa, 1983; Ehiro et al., 1988; Ozawa et al., 1988). The data points define a Sm-Nd age of $510 \pm 70 \mathrm{Ma}$ and an initial ${ }^{143} \mathrm{Nd} /{ }^{144} \mathrm{Nd}$ ratio of $0.51229 \pm 0.00010$ $(\mathrm{MSWD}=0.91)$. The initial $\varepsilon_{\mathrm{Nd}}$ calculated using the parameters in Table 3 is $+6.4 \pm 2.0$. The $\varepsilon_{\mathrm{Nd}}$ calculated at $510 \mathrm{Ma}$ for each sample ranges from +6.3 to +7.0 (Table 3). Although the er-

Table 2. $K$-Ar ages of hornblendes from the Hayachine-Miyamori ophiolitic complexes

\begin{tabular}{|c|c|c|c|c|c|c|}
\hline Sample no. & Rock & Mineral & $\begin{array}{l}\mathrm{K}_{2} \mathrm{O} \\
(\%)\end{array}$ & $\left(10^{-6} \mathrm{ml} \mathrm{STP} / \mathrm{g}\right)$ & $\underset{(\%)}{\operatorname{Atm} .}{ }^{40} \mathrm{Ar}$ & $\begin{array}{l}\text { Age } \\
\text { (Ma) }\end{array}$ \\
\hline \multicolumn{7}{|c|}{ Hayachine complex } \\
\hline HY-5 & Hb gabbro & Hornblende & 0.129 & 2.06 & 49.1 & $437 \pm 17$ \\
\hline HY-9 & Amphibolite & Hornblende & 0.137 & 2.39 & 62.2 & $473 \pm 24$ \\
\hline HY-12 & Metagabbro & Hornblende & 0.134 & 1.13 & 49.0 & $244 \pm 10$ \\
\hline HY-15 & Cpx-hb gabbro & Hornblende & 0.121 & 1.24 & 57.3 & $292 \pm 13$ \\
\hline HY-16 & Cpx-hb gabbro & Hornblende & 0.106 & 1.22 & 42.6 & $325 \pm 12$ \\
\hline \multirow[t]{2}{*}{ HY-20 } & Hb gabbro & Hornblende & 0.294 & 4.91 & 37.9 & $455 \pm 16$ \\
\hline & & Hornblende $(\mathrm{HCl})$ & 0.293 & 4.86 & 28.1 & $452 \pm 15$ \\
\hline \multirow[t]{2}{*}{ НYТН3Р } & Amphibolite & Hornblende & $0.135,0.133$ & 2.04 & 55.7 & $418 \pm 18$ \\
\hline & & & & 1.96 & 44.6 & $\frac{404 \pm 15}{411+12}$ \\
\hline \multicolumn{7}{|c|}{ Miyamori complex } \\
\hline HY-23 & Hb clinopyroxenite & Hornblende & 0.133 & 2.30 & 40.2 & $469 \pm 17$ \\
\hline
\end{tabular}

Table 3. Sm-Nd isotopic data for the Hayachine-Miyamori ophiolitic complexes

\begin{tabular}{ccccccc}
\hline Sample no. & Rock & $\begin{array}{c}\mathrm{Sm} \\
(\mathrm{ppm})\end{array}$ & $\begin{array}{c}\mathrm{Nd} \\
(\mathrm{ppm})\end{array}$ & ${ }^{147} \mathrm{Sm} /{ }^{144} \mathrm{Nd}$ & ${ }^{143} \mathrm{Nd} /{ }^{144} \mathrm{Nd}^{*}$ & $\varepsilon_{\mathrm{Nd}}{ }^{* *}$ \\
\hline HY-5 & Hb gabbro & 0.200 & 0.521 & 0.2322 & $0.51307 \pm 2$ & $+6.6 \pm 0.4$ \\
HY-9 & Amphibolite & 2.93 & 7.78 & 0.2278 & $0.50304 \pm 2$ & $+6.3 \pm 0.4$ \\
HY-23 & Hb clinopyroxenite & 1.29 & 4.20 & 0.1858 & $0.51291 \pm 2$ & $+6.4 \pm 0.4$ \\
HY-24 & Ol hornblendite & 2.85 & 7.54 & 0.2287 & $0.51308 \pm 6$ & $+7.0 \pm 1.2$ \\
\hline
\end{tabular}

\footnotetext{
*Errors are $2 \sigma$ mean.

${ }^{* *}$ Values at $510 \mathrm{Ma}$, calculated using present ${ }^{143} \mathrm{Nd} /{ }^{144} \mathrm{Nd}$ and ${ }^{147} \mathrm{Sm} /{ }^{144} \mathrm{Nd}$ for CHUR: 0.51264 and 0.1966 (Wasserburg et al., 1981).
} 


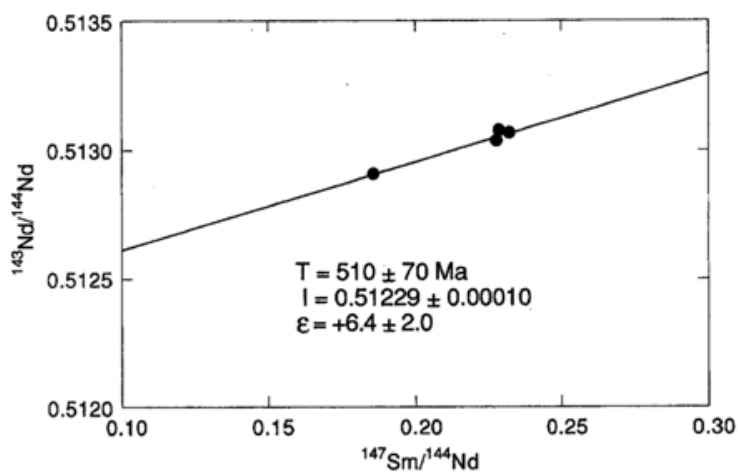

Fig. 2. Sm-Nd isochron diagram for whole-rock samples from the Hayachine-Miyamori ophiolite.

ror in age is relatively large owing to a limited range in ${ }^{147} \mathrm{Sm} /{ }^{144} \mathrm{Nd}$ ratio, the age of $510 \mathrm{Ma}$ predates the $\mathrm{K}-\mathrm{Ar}$ hornblende ages, and is interpreted to be the crystallization age of the Hayachine-Miyamori ophiolite. The $\varepsilon_{\mathrm{Nd}}$ of +6.4 is slightly lower than that of the MORB even corrected for the age of $510 \mathrm{Ma}$ and is within the range of island arc tholeiites.

$\mathrm{Rb}-\mathrm{Sr}$ isotopic data are given in Table 4. Initial ${ }^{87} \mathrm{Sr} /{ }^{86} \mathrm{Sr}$ ratios calculated for the $\mathrm{Sm}-\mathrm{Nd}$ age of $510 \mathrm{Ma}$ show a wide variation from 0.70361 to 0.70614 , corresponding to $\varepsilon_{\mathrm{Sr}}$ of -4.0 to +31.9 . The pattern of limited $\varepsilon_{\mathrm{Nd}}$ and variable $\varepsilon_{\mathrm{Sr}}$ is similar to that of the Bay of Islands (Jacobsen and Wasserburg, 1979) and Samail (McCulloch et al., 1980) ophiolites, suggesting the effect of seawater alteration. This problem will be discussed later.

\section{Discussion}

\section{Evaluation of $K-A r$ ages}

The investigated rocks show a large variation in degree of secondary alteration or low-temperature metamorphism, although they are supposed to have been equilibrated at higher amphibolite facies as indicated by their primary assemblage of brown hornblende, clinopyroxene, and probably calcic plagioclase. Total modal percentage of the secondary mafic minerals ranges from 2 to $43 \%$, in which secondary amphibole occupies the most of them (Table 1). The obtained $\mathrm{K}-\mathrm{Ar}$ ages of hornblende show significantly wide range

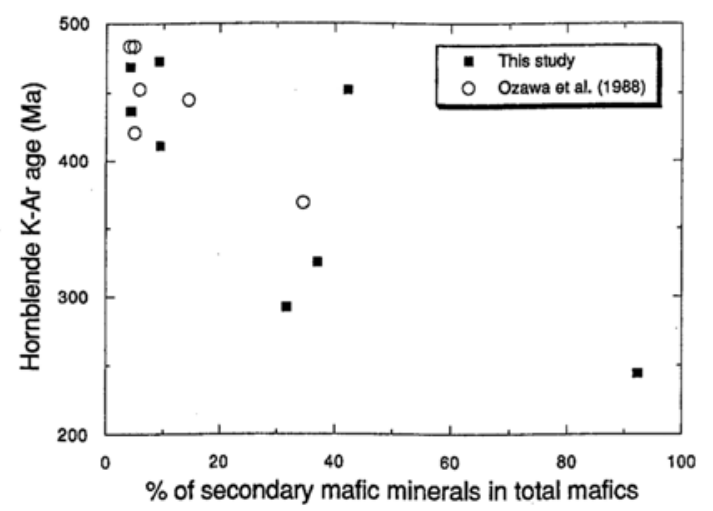

Fig. 3. Percentage of secondary mafic minerals in total mafics against hornblende $K-A r$ ages.

from 244 to $473 \mathrm{Ma}$. In order to evaluate the effects of these secondary processes, $\mathrm{K}-\mathrm{Ar}$ ages are plotted against percentage of secondary mafic minerals in total mafic minerals in each rock as an indicator of degree of alteration and/or metamorphism (Fig. 3).

$\mathrm{K}$-Ar ages exhibit negative correlation with the percentage of secondary mafic minerals as a whole, which is consistent with the data on the Miyamori complex (Ozawa et al., 1988). This correlation clearly suggests that $\mathrm{K}-\mathrm{Ar}$ ages are reset by a metamorphism that took place in ages younger than $\sim 250 \mathrm{Ma}$ in those rocks with abundant secondary mafic minerals. Metagabbro HY-12 with highest percentage of secondary amphibole indicates $244 \mathrm{Ma} \mathrm{K}-\mathrm{Ar}$ age, of which younger age may be attributable to one of small Cretaceous granitic intrusives commonly occurring in the western part of the Hayachine Tectonic Belt. The locality is $2 \mathrm{~km}$ to the south of outcrops of metaperidotite with metamorphic assemblage of talc, tremolite, and olivine. This assemblage indicates metamorphic temperature higher than $700^{\circ} \mathrm{C}$. Amphibolite HYTH3P, sampled $1.4 \mathrm{~km}$ to the east of HY-12 locality yields $411 \mathrm{Ma}$, and amphibolite HY-9 sampled $1.5 \mathrm{~km}$ to the southeast of HYTH3P locality yields $473 \mathrm{Ma}$. Very fresh peridotites with small amount of lizardite and chrysotile as serpentine minerals are cropped out near HY-9. The abundance of secondary mafic phase decreases and $\mathrm{K}-\mathrm{Ar}$ age increases from HY12 to HY-9 through 
HYTH3P, suggesting that thermal effect of the Cretaceous granitic intrusive decreases from the west to the east in this region, and that $473 \mathrm{Ma}$ is a reasonable estimation of cooling age for the Hayachine ophiolitic complex. Two samples from the Kagura body indicating $\mathrm{K}-\mathrm{Ar}$ ages of 292 and $325 \mathrm{Ma}$ contain abundant secondary mafic minerals and they are eventually sampled closer to the Tono granitic intrusion. Peridotites occurring near the sampled gabbros have metamorphic mineral assemblage of antigorite and olivine, which is consistent with observed younger ages for the gabbros as in the case of the Miyamori complex (Ozawa et al., 1988).

Gabbro HY-20 sampled from a locality to the west of Kamaishi is exceptional, indicating 452 and $455 \mathrm{Ma} \mathrm{K}-\mathrm{Ar}$ ages, although it contains considerable amounts of secondary amphibole. Petrographic observation demonstrates that secondary amphibole was mostly derived from the replacement of clinopyroxene. The granite outcrop nearest to the gabbro locality is $10 \mathrm{~km}$ to the south. Serpentinized ultramafic rock occurring within a few hundred meter to the south of this locality is characterized by static replacement of olivine by lizardite and/or chrysotile assemblage, and no antigorite is present. These facts strongly suggest that contact metamorphism by Cretaceous granitic intrusives did not cause replacement of those clinopyroxene in this region. The alteration of clinopyroxene could have been related to the emplacement stage taking place at $\sim 450 \mathrm{Ma}$.

Excepting the samples containing abundant secondary amphibole and occurring close to the granitic intrusions, obtained $\mathrm{K}-\mathrm{Ar}$ ages range from 437 to $473 \mathrm{Ma}$, which coincide with the KAr ages $(421 \sim 484 \mathrm{Ma})$ obtained for the Miyamori complex (Ozawa et al., 1988). This coincidence strongly supports the idea that the Miyamori complex is a displaced portion of the Hayachine ophiolitic complex, proposed by Ozawa (1984).

\section{Sm-Nd age and its relationship to $K-A r$ age}

A Sm-Nd whole-rock isochron age of plutonic rocks is generally interpreted to indicate a crystallization age, because the Sm-Nd system is less susceptible to alteration and metamorphism than the $\mathrm{Rb}-\mathrm{Sr}$ and $\mathrm{K}-\mathrm{Ar}$ systems. Therefore, the Sm-Nd whole-rock age of $510 \pm 70 \mathrm{Ma}$ is interpreted to be the time of crystallization of gabbroic rocks of the Hayachine-Miyamori ophiolite in the mantle or in the lower crust.

$\mathrm{K}-\mathrm{Ar}$ ages for hornblendes from the Hayachine-Miyamori ophiolite range from 421 to $484 \mathrm{Ma}$, excluding younger ages caused by granitic intrusions. The closure temperature of Ar diffusion in hornblende is estimated to be about $500^{\circ} \mathrm{C}$. Thus $\mathrm{K}-\mathrm{Ar}$ ages of $421-484 \mathrm{Ma}$ for hornblendes indicate the times when the Hayachine-Miyamori ophiolite cooled to about $500^{\circ} \mathrm{C}$ after the formation. These ages could indicate either the times of tectonic emplacement to shallower levels or late stage tectonic disturbance. The time difference between the Sm-Nd age and the oldest hornblende age: $30 \mathrm{Ma}$, may therefore be the period between the crystallization and tectonic emplacement of the Hayachine-Miyamori ophiolite. However, a large error in the Sm-Nd age makes it difficult to further discuss this time difference. It appears that the tectonic emplacement occurred soon after the crystallization at least in some part of the Hayachine-Miyamori ophiolite.

\section{$\mathrm{Nd}$ and $\mathrm{Sr}$ isotopic systematics and origin of the Hayachine-Miyamori complexes}

The initial isotopic compositions of $\mathrm{Sr}$ calculated for the $510 \mathrm{Ma}$ Sm-Nd age show very wide variation ranging from -4.0 to +31.9 for $\varepsilon_{\mathrm{Sr}}$, and from 0.70361 to 0.70614 for initial ${ }^{87} \mathrm{Sr} /{ }^{86} \mathrm{Sr}$ ratio (Table 4). This wide variation is true even if highly altered gabbros are excluded. There is no over-all systematic correlation between initial ${ }^{87} \mathrm{Sr} /{ }^{86} \mathrm{Sr}$ ratio and abundance of secondary mafic minerals. For highly altered gabbros, which give younger $\mathrm{K}-\mathrm{Ar}$ ages, the ratio tends to decrease as secondary mafic minerals increase, but for fresh samples it shows wide variation without any correlation with the abundance of secondary mafic minerals. This fact clearly indicates that late-stage metamorphism or altera- 
Table 4. $\quad \mathrm{Rb}-\mathrm{Sr}$ isotopic data for the Hayachine-Miyamori ophiolitic complexes

\begin{tabular}{|c|c|c|c|c|c|c|c|}
\hline Sample no. & Rock & $\underset{(\mathrm{ppm})}{\mathrm{Rb}}$ & $\underset{(\mathrm{ppm})}{\mathrm{Sr}}$ & ${ }^{87} \mathrm{Rb} /{ }^{86} \mathrm{Sr}$ & ${ }^{87} \mathrm{Sr} /{ }^{86} \mathrm{Sr}$ & $\left({ }^{87} \mathrm{Sr} /{ }^{86} \mathrm{Sr}\right)_{0}^{* *}$ & $\varepsilon_{\mathrm{Sr}}{ }^{* * *}$ \\
\hline \multicolumn{8}{|c|}{ Hayachine complex } \\
\hline HY-5 & Hb gabbro & $22.77^{*}$ & $342.8^{*}$ & 0.1924 & 0.70500 & 0.70361 & -4.0 \\
\hline HY-9 & Amphibolite & 3.4 & 233 & 0.042 & 0.70644 & 0.70614 & +31.9 \\
\hline HY-12 & Metagabbro & 7.5 & 312 & 0.070 & 0.70467 & 0.70416 & +3.9 \\
\hline HY-15 & Cpx-hb gabbro & $0.868^{*}$ & 405 & 0.0062 & 0.70504 & 0.70500 & +15.7 \\
\hline HY-20 & Hb gabbro & 3.9 & 110 & 0.079 & 0.70488 & 0.70431 & +5.9 \\
\hline HYTH3P & Amphibolite & 1.1 & 128 & 0.025 & 0.70454 & 0.70439 & +6.7 \\
\hline \multicolumn{8}{|c|}{ Miyamori complex } \\
\hline HY-23 & Hb clinopyroxenite & $0.817^{*}$ & 55.6 & 0.043 & 0.70456 & 0.70425 & +5.1 \\
\hline HY-24 & Ol hornblendite & $0.103^{*}$ & 65.6 & 0.0045 & 0.70507 & 0.70504 & +16.3 \\
\hline
\end{tabular}

*Isotope dilution; others $X$-ray fluorescence.

***Values at $510 \mathrm{Ma}$.

*** Values at $510 \mathrm{Ma}$, calculated using present ${ }^{87} \mathrm{Sr} /{ }^{86} \mathrm{Sr}$ and ${ }^{87} \mathrm{Rb} /{ }^{86} \mathrm{Sr}$ for UR: 0.7045 and 0.0839 (DePaolo and Wasserburg, 1976).

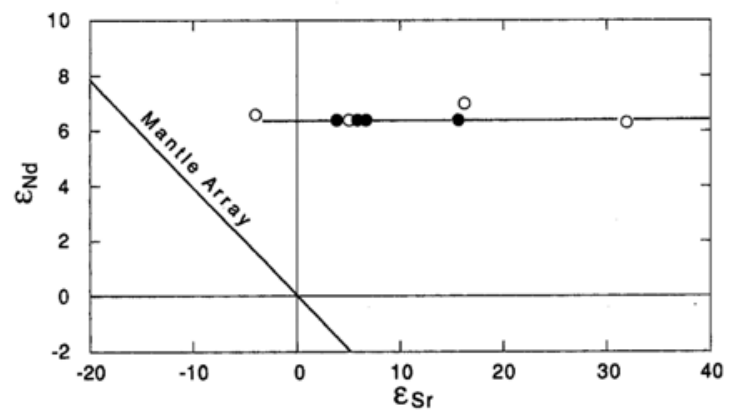

Fig. 4. $\varepsilon_{S r}-\varepsilon_{N d}$ diagram for the HayachineMiyamori ophiolite. Closed circles represent samples of which $\varepsilon_{N d}$ values are assumed to be +6.4 . The horizontal line is a part of mixing curve between the uncontaminated rock and the Ordovician seawater.

tion does not account for the wide variation of initial ${ }^{87} \mathrm{Sr} /{ }^{86} \mathrm{Sr}$ ratio.

In contrast to the wide variation of $\varepsilon_{\mathrm{Sr}}, \varepsilon_{\mathrm{Nd}}$ is almost constant ranging from 6.3 to 7.0 giving rise to a nearly horizontal trend on an $\varepsilon_{\mathrm{Sr}}-\varepsilon_{\mathrm{Nd}}$ diagram (Fig. 4). This trend coincides with that reported from the Bay of Islands Complex, which is attributed to the seawater alteration (Jacobsen and Wasserburg, 1979). The sample with highest $\varepsilon_{\mathrm{Sr}}$ is amphibolite $(+31.9)$, which is supposed to be metamorphosed basalt, diabase dike, or gabbro. Another amphibolite HYTH3P also indicates the second highest $\varepsilon_{\mathrm{Sr}}$ value of +6.7 if gabbros with high modal abundance of secondary mafic phases and olivine hornblendite
HY-24 are excluded. HY-24, which is peculiar in the presence of olivine, orthopyroxene, and spinel, absence of plagioclase, higher $\mathrm{Mg} \#$ of mafic phases, and higher concentration of $\mathrm{K}_{2} \mathrm{O}$ in hornblende $(0.236 \mathrm{wt} \%)$, has the highest $\varepsilon_{\mathrm{Nd}}$ of 7.2. Its $\varepsilon_{\mathrm{Sr}}$ is also relatively high and indicates +16.3 . The other two samples are coarse-grained hornblende gabbro and hornblende clinopyroxenite which preserve magmatic textures under slow cooling condition. This correlation between rock type and $\varepsilon_{\mathrm{Sr}}$ is consistent with the idea that the wide ${ }^{87} \mathrm{Sr} /{ }^{86} \mathrm{Sr}$ ratio is originated from various degree of seawater interaction with a cooling magma system; extrusive or shallow intrusive rocks were highly interacted with seawater and recrystallized into amphibolite with strong lineation, whereas plutonic rocks were not. This is similar to the Bay of Island complex, in which metagabbro, trondhjemite, and sheeted dikes give higher $\varepsilon_{\mathrm{Sr}}$, whereas fresh gabbros and peridotites give lower $\varepsilon_{\mathrm{Sr}}$ (Jacobsen and Wasserburg, 1979).

The elevated initial ${ }^{87} \mathrm{Sr} /{ }^{86} \mathrm{Sr}$ for the gabbroic rocks could be explained by seawater circulation, but these hornblende gabbros and hornblendites are present as intrusives in ultramafic rocks, suggesting that seawater circulation during the formation of shallower crust may not be responsible for the origin of their high $\varepsilon_{\mathrm{Sr}}$. Even if amphibolites are neglected, the data are plot- 
ted above the Mantle Array, the fact of which have been reported from some island arc volcanic rocks (Hawkesworth et al., 1977; Hawkesworth et al., 1979; Whitford et al., 1981). The $\varepsilon_{\mathrm{Nd}}$ values are lower than those of MORB and are within the range of some island arc volcanic rocks (Nohda and Wasserburg, 1981; McCulloch and Perfit, 1981).

The fact that enrichment in radiogenic $\mathrm{Sr}$ can be observed in the mantle of the HayachineMiyamori ophiolite is very important, because any shallow processes may not account for the high ${ }^{87} \mathrm{Sr} /{ }^{86} \mathrm{Sr}$ ratio of coarse-grained basic intrusion in the mantle peridotites, which preserve high pressure-temperature primary assemblages. There is no evidence for the participation of crustal contamination in the formation of the ophiolite. The $\varepsilon_{\mathrm{Nd}}-\varepsilon_{\mathrm{Sr}}$ systematics is a mantle geochemical signature, although mantle peridotites or pyroxenites have to be analyzed for the confirmation, which is an important future work.

On the basis of mineralogic data of amphibole in peridotites, Ozawa $(1988,1990)$ argued that the Miyamori complex was formed in an arc environment. Yoshida et al. (1990) reported that extrusive rocks from the Hayachine Tectonic Belt show geochemical characteristics of arc magmatism. Olivine-phyric basalts occurring as volcanic breccia in the southwestern part of the Hayachine ophiolitic complex is highly vesiculated, even if it is quite primitive. The high vesicularity suggests high water content unless they erupted on very shallow ocean basin (Dick, 1980). Spinel phenocrysts and inclusions in altered olivine phenocrysts of those basalts exhibit $\mathrm{Cr} \#$ as high as that in chromian spinel peridotites of the Miyamori complex (Ozawa, 1988). As shown in Fig. 5, the spinel compositions are partly within the range of boninite and high- $\mathrm{Mg}$ andesite (Dick and Bullen, 1984). Some of them are within MORB area, but they tend to show higher ferric and ferrous contents, suggesting crystallization from evolved melt. All these data suggest that the Hayachine-Miyamori ophiolite represents a section of arc crust and upper man-

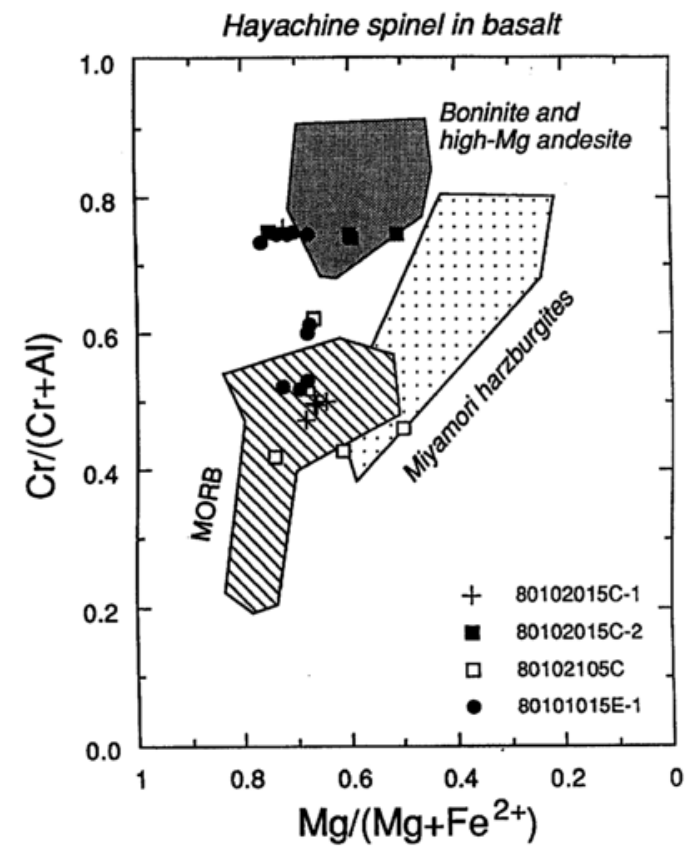

Fig. 5. Composition of spinel in basalts from the Hayachine Tectonic Belt. Spinel grains occur as phenocrysts of tiny inclusions in olivine phenocrysts, which are completely altered into chlorite. Sampling localities are Otsube to the east of Hizume.

tle. The high initial ${ }^{87} \mathrm{Sr} /{ }^{86} \mathrm{Sr}$ ratio of the Hayachine-Miyamori ophiolite, therefore, should be considered in this context.

Gabbroic rocks in the Miyamori complex are distributed in residual peridotites as elongate bodies (Ozawa, 1984). As Seki (1952) demonstrated, at least some of them are dikes intruded into the host peridotites. These dikes, whose contact relationships with its host can be observed, are small, usually less than a meter in thickness, and mostly hronblendite or clinopyroxene hornblendite. They do not contain plagioclase at all. A large gabbroic body occurring to the north of Miyamori has thick selvage of hornblendite on the both sides (Ozawa, 1983). The occurrence of hornblendite between hornblende gabbro and peridotite suggests reaction between hydrous basic melt and host peridotites. The cumulate member of the Miyamori complex represents late stage cumulate body intruded into the tectonite member (Ozawa, 1983). The common occur- 
rence of late intrusions often associated with reaction zone may be highly expected in the arc upper mantle, where magma may be supplied repeatedly. The observed high $\varepsilon_{\mathrm{Sr}}$ and low $\varepsilon_{\mathrm{Nd}}$ for these intrusives may represent isotopic characteristics of the arc magmatisms that took place in the Hayachine-Miyamori ophiolite. This isotopic signature may be attributable to the involvement of altered old oceanic crust or terrigenous sediments subducted beneath the Hayachine-Miyamori arc in the Ordovician time.

Acknowledgments-We wish to thank Dr. T. Tanaka of Nagoya University for assistance and discussion in Sm-Nd dating, and Mr. S. Uchiumi of the Geological Survey of Japan for assistance in $\mathrm{K}-\mathrm{Ar}$ dating.

\section{REFERENCES}

DePaolo, D. J. and Wasserburg, G. J. (1976) Inferences about magma sources and mantle structure from variations of ${ }^{143} \mathrm{Nd} /{ }^{144} \mathrm{Nd}$. Geophys. Res. Lett. 3, 743-746.

Dick, H. J. B. (1980) Vesicularity of Shikoku Basin basalt: a possible correlation with the anomalous depth of back-arc basins. Init. Rep. Deep Sea Drilling Proj. 58, 895-904.

Dick, H. J. B. and Bullen, T. (1984) Chromian spinel as a pertrogenetic indicator in abyssal and alpinetype peridotites and spatially associated lavas. Contrib. Mineral. Petrol. 86, 54-76.

Dick, H. J. B. and Fisher, R. L. (1984) Mineralogic studies of the residues of mantle melting: abyssal and alpine-type peridotites. In: Kornprobst, J. ed., Kimberlites II: The Mantle and Crust-Mantle Relationships, Elsevier, Amsterdam, 295-308.

Ehiro, M. (1977) The Hizume-Kesennuma fault, with special reference to the character and significance on the geologic development. Contr. Inst. Geol. Pal. Tohoku Univ. No. 77, 1-37 (in Japanese with English abstract).

Ehiro, M., Okami, K. and Kanisawa, S. (1988) Recent progress and further subjects in studies on the "Hayachine Tectonic Belt" in the Kitakami Massif, Northeast Japan., Earth Science 42, 317-335 (in Japanese with English abstract).

Hawkesworth, C. J., O'Nions, R. K., Pankhurst, R. J., Hamilton, P. J. and Evensen, N. M. (1977) A geochemical study of island-arc and back-arc tholeiites from the Scotia Sea. Earth Planet. Sci. Lett. 36, 253-262.
Hawkesworth, C. J., O'Nions, R. K. and Arculus, R. J. (1979) $\mathrm{Nd}$ and $\mathrm{Sr}$ isotope geochemistry of island arc volcanics, Grenada, Lesser Antilles. Earth Planet. Sci. Lett. 45, 237-248.

Jacobsen, S. B. and Wasserburg, G. J. (1979) Nd and Sr isotopic study of the Bay of Island ophiolite complex and evolution of the source of midocean ridge basalts. J. Geophys. Res. 84, 7429-7445.

Kato, M. (1985) Paleozoic and Mesozoic strata of the Kitakami Mountains, Japan: an overview. Mem. Geol. Soc. Japan No. 25, 19-29 (in Japanese with English abstract).

Lugmair, G. W. and Carlson, R. W. (1978) The SmNd history of KREEP. Proc. 9th Lunar Planet. Sci. Conf., 689-704.

McCulloch, M. T. and Perfit, M. R. (1981) ${ }^{143} \mathrm{Nd} /$ ${ }^{144} \mathrm{Nd},{ }^{87} \mathrm{Sr} /{ }^{86} \mathrm{Sr}$ and trace elements constraints on the petrogenesis of Aleutian Island arc magmas. Earth Planet. Sci. Lett. 56, 167-179.

McCulloch, M. T., Gregory, R. T., Wasserburg, G. J. and Taylor, H. P. Jr. (1980) A neodymium, strontium, and oxygen isotopic study of the Cretaceous Samail ophiolite and implications for the petrogenesis and seawater-hydrothermal alteration of oceanic crust. Earth. Planet. Sci. Lett. 46, 201211.

Nohda, S. and Wasserburg, G. J. (1981) Nd and Sr isotopic study of volcanic rocks from Japan. Earth Planet. Sci. Lett. 52, 264-276.

Okami, K. and Oishi, M. (1983) On the metamorphic rock distributed in the Hayachine ultramafic rocks, Kitakami Mountains, northeast Japan. J. Geol. Soc. Japan 89, 362-364 (Japanese).

Onuki, H. (1962) Petrochemical study of the Kagura ultramafic body, Kitakami mountainland. J. Japan. Assoc. Min. Petr. Econ. Geol. 48, 1-10 (in Japanese with English abstract).

Onuki, Y. (1969) Geology of the Kitakami massif, Northeast Japan. Contr. Inst. Geol. Pal. Tohoku Univ. No. 69, 1-239 (in Japanese with English abstract).

Osawa, M. (1983) Geological study on the “Hayachine Tectonic Belt". Contr. Inst. Geol. Pal. Tohoku Univ. No. 85, 1-30 (in Japanese with English abstract).

Ozawa, K. (1983) Relationships between tectonite and cumulate in ophiolites: the Miyamori ultramafic complex, Kitakami Mountains, northeast Japan. Lithos 16, 1-16.

Ozawa, K. (1984) Geology of the Miyamori ultramafic complex in the Kitakami Mountains, northeast Japan. J. Geol. Soc. Japan 90, 697-716.

Ozawa, K. (1988) Ultramafic tectonite of the Miyamori ophiolitic complex in the Kitakami Mountains, northeast Japan: hydrous upper mantle in an 
island arc. Contrib. Mineral. Petrol. 99, 159-175.

Ozawa, K. (1990) Origin of the Miyamori ophiolitic complex, northeast Japan: $\mathrm{TiO}_{2} / \mathrm{K}_{2} \mathrm{O}$ of amphibole and $\mathrm{TiO}_{2} / \mathrm{Na}_{2} \mathrm{O}$ of clinopyroxene as discriminants for the tectonic setting of ophiolites. Proc. Ophiolite Conf., Cyprus, Nicosia, 1987, 485-495.

Ozawa, K. and Shimizu, N. (1991) Mechanism of magma generation in an arc upper mantle: constraints from REE patterns of amphibole and clinopyroxene in the Miyamori-Hayachine peridotites, northeast Japan. EOS 72, 519.

Ozawa, K., Shibata, K. and Uchiumi, S. (1988) K-Ar ages of hornblende in gabbroic rocks from the Miyamori ultramafic complex of the Kitakami Mountains. J. Min. Petr. Econ. Geol. 83, 150-159 (in Japanese with English abstract).

Pearce, J. A., Lippard, S. J. and Roberts, S. (1984) Characteristics and tectonic significance of suprasubduction zone ophiolites. In: Kokelaar, B. P. and Howells, M. F. eds., Marginal Basin Geology. Geological Society of London Special Publication, No. 16: 77-89.
Saito, Y. and Hashimoto, M. (1982) South Kitakami region: An allochtonous terrane in Japan. $J$. Geophys. Res. 87, 3691-3696.

Seki, Y. (1952) The studies on Miyamori ultrabasic mass, Iwate Prefecture, N-E Japan (No. 4):-On the structural studies-. J. Geol. Soc. Japan 58, 505-516 (in Japanese with English abstract).

Wasserburg, G. J., Jacobsen, S. B., DePaolo, D. J., McCulloch, M. T. and Wen, T. (1981) Precise determination of $\mathrm{Sm} / \mathrm{Nd}$ ratios, $\mathrm{Sm}$ and $\mathrm{Nd}$ isotopic abundances in standard solutions. Geochim. Cosmochim. Acta 45, 2311-2323.

Whitford, D. J., White, W. M. and Jezek, P. A. (1981) Neodymium isotopic composition of Quaternary island arc lavas from Indonesia. Geochim. Cosmochim. Acta 45, 989-995.

York, D. (1966) Least squares fitting of a straight line. Can. J. Phys. 44, 1079-1086.

Yoshida, T., Kanisawa, S. and Ehiro, M. (1990) Trace element composition of the Hayachine complex. $J$. Min. Petrol. Econ. Geol. 85, 183 (Japanese). 